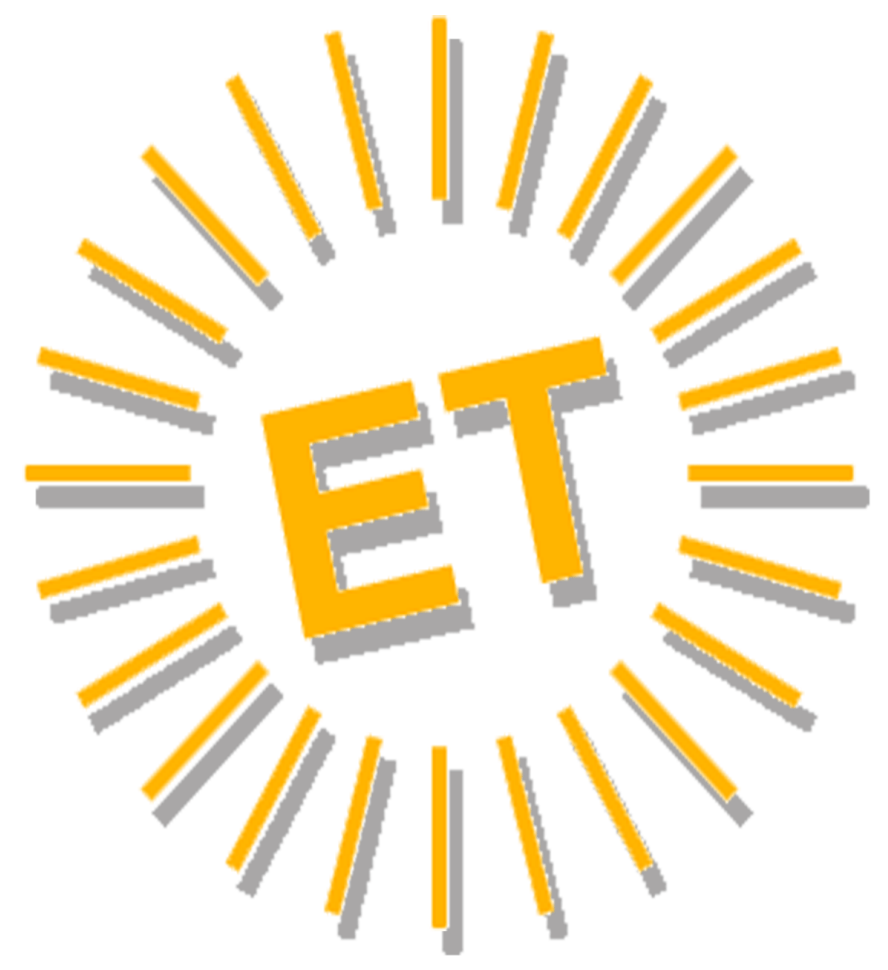




\section{Editorial Team}

\section{Editor in Chief}

Alfonso Vargas-Sánchez, University of Huelva, Spain

\section{Associate Editor}

Mirko Perano, Reald University College, Albania

\section{Books Review Editor}

Brendan Paddison, York St. John University, United Kingdom

\section{Secretariat}

Elena García de Soto, University of Huelva, Spain

Cinta Borrero-Domínguez, University of Seville, Spain

\section{Style reviewer and text editor}

Anestis Fotiadis, Zayed University, United Arab Emirates

\section{Editorial Board}

José Manuel Alcaraz, Murdoch University, Australia Mario Castellanos-Verdugo, University of Seville, Spain José Antonio Fraiz-Brea, University of Vigo, Spain José Manuel Hernández-Mogollón, University of Extremadura, Spain

Tzung-Chen Huan, National Chiayi University, Taiwan, Province of China

Shaul Krakover, Ben Gurion University, Israel Jean Pierre Levy-Mangin, University of Quebec, Canada Tomás López-Guzmán, University of Córdoba, Spain Yasuo Ohe, Chiba University, Japón

María de los Ángeles Plaza-Mejía, University of Huelva, Spain Nuria Porras-Bueno, University of Huelva, Spain João Albino Silva, Algarve University, Portugal

\section{Advisory Board (Spanish Members)}

Juan Manuel Berbel-Pineda, Pablo de Olavide University, Spain César Camisón-Zornoza, Uniersity of Valencia, Spain Enrique Claver-Cortés, University of Alicante, Spain María Teresa Fernández-Alles, University of Cádiz, Spain José Luis Galán-González, University of Seville, Spain Félix Grande-Torraleja, University of Jaén, Spain

Antonio Leal-Millán, University of Seville, Spain Inmaculada Martín-Rojo, University of Málaga, Spain Antonio Manuel Martínez-López, University of Huelva, Spain Francisco José Martínez-López, University of Huelva, Spain Pablo A. Muñoz-Gallego, University of Salamanca, Spain
Francisco Riquel-Ligero, University of Huelva, Spain José Miguel Rodríguez-Antón, Autonomous University of Madrid, Spain

Sandra Sanchez-Cañizares, University of Cordoba, Spain Josep Francesc Valls-Giménez, ESADE, Spain

\section{Advisory Board (Other European Members)}

Tindara Abbate, University of Messina, Italy Paulo Aguas, University of Algarve, Portugal Carlos Costa, Aveiro University, Portugal Dianne Dredge, Aalborg University, Denmark Salvatore Esposito de Falco, University of Rome "La Sapienza", Italy

Sheila Flanagan, Dublín Institute of Technology, Ireland Tania Gorcheva, Tsenov Academy of Economics, Bulgaria Tadeja Jere Jakulin, University of Primorska, Slovenia Metin Kozak, Mugla University, Turkey Álvaro Matias, Lusiada University, Portugal Alfonso Morvillo, National Research Council, Italy Alexandru Nedelea, Stefan cel Mare University of Suceava, Romania Claudio Nigro, University of Foggia, Italy Angelo Presenza, University "G. D'Annunzio" of Chieti-Pescara, Italy

Kanes Rajah, Royal Agricultural University, United Kingdom

\section{Advisory Board (Members from the rest of the world)}

John Allee, American University of Sharjah, United Arab Emirates

Nestor Pedro Braidot, National University of La Plata, Argentina

Roberto Elias Canese, Columbia University, Rector, Paraguay

Luca Casali, Queensland University of Technology, Australia Nimit Chowdhary, Indian Institute of Tourism and Travel Management, India

Steven Chung-chi Wu, National Pingtung University of Science and Technology, Taiwán

Dianne Dredge, Southern Cross University, Australia Daniel Fesenmaier, Temple University, United States

Babu George, Alaska Pacific University, United States Dogan Gursoy, Washington State University, United States Jafar Jafari, University of Wisconsin-Stout, United States Sanggun Lee, Pai Chai University, Korea Republic of Albert Yeh Shangpao, I-SHOU University, Taiwán Pauline Sheldon, University of Hawaii, United States Germán A. Sierra-Anaya, University of Cartagena de Indias, Rector, Colombia Xiaohua Yang, University of San Francisco, United States 


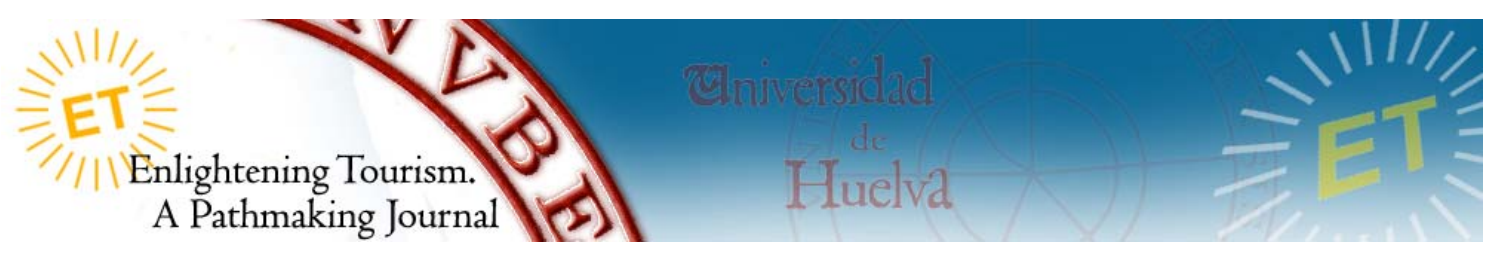

\title{
LUXURY HOSPITALITY SERVICE ADOPTION AMONGST INDIAN MILLENNIALS: AN ANALYTICAL APPROACH
}

\author{
Sudhanshu Gupta \\ J\&K Directorate of Horticulture Planning \& Marketing (India) \\ sudhanshugupta45@gmail.com \\ Parvinder Kour \\ Lovely Professional University (India) \\ parvinder.25666@lpu.co.in
}

\begin{abstract}
Understanding the Indian millennial travelers is vital in providing insights into their behavior while presenting additional challenges to successfully targeting different demographic cohorts for luxury products and services. The present study investigates the factors that define the value perceptions and attitude of Millennials towards luxury service consumption in India. The findings revealed social value as an important factor that influences the attitude of millennial consumers towards purchasing luxury tourism services. Along with providing a theoretical model for behavior, the study provides insights into measuring tourist value preferences by utilizing empirical data within luxury tourism contexts and suggests the tourism and hospitality business practitioners to make innovations in product, service management, and marketing to draw the attention of such a potential segment. Moreover, this study augments the existing knowledge of luxury value and travel patterns of emerging and potential consumers while developing a theoretical model to validate and analyze the luxury service consumption amongst them.
\end{abstract}

\section{KEYWORDS}

Behavioral Intentions; Experiential Values; Luxury Hospitality Service; Millennials 
ECONLIT KEYS

L80; L83; M31; Z31; Z32

\section{INTRODUCTION}

Consumption of luxury is not restricted to a person's physiological needs but extends to improving personal characteristics and individualities within the society. The world has witnessed a considerable drift in the consumption of luxury among consumers from products towards more or less luxury experiences like tourism, which is growing more rapidly than luxury goods (Deloitte, 2017). With the increasing trends and more disposable incomes of the people especially the middle class, the tourists are seen to look for more comfortable and exclusive holiday experiences and services. Hanzaee and Sadeghian (2014) considered it as an exclusive aspect of consumer behavior. It involves all categories of tourists and is not labeled by their level of income or earnings only if they can afford to buy those luxurious services (Popescu \& Olteanu, 2014) and also Dykins (2016) in her report for Connections and Amadeus IT Group titled "Shaping the Future of Luxury Travel: Future Traveller Tribes 2030" noted that India's thriving middle-class population represents an immense potential for investment in luxury travel. Being more categorical, these are amongst aspiring luxury travelers (who at least hold US\$1 million in their monetary assets).

Horwath HTL's report supported by International Luxury Travel Market (Horwath HTL's report, 2011, p.4) categorizes such luxury travelers as "the candidates who aspire luxury to a high level of comfort and quality and considers travel with the concept of social status and luxury services". They tend to be followers than initiators in their decision for destination selection". In contrast to this, millennials are more inclined towards purchasing ephemeral services and luxury experiences over other tangible products (Falk, 2017; Seo, Kelleher \& Brodie, 2017). Millennials are consumers of the new generation characterized as confident, team-oriented, and achieving type (Howe, 2006). They (millennials) are also considered as the generation with high purchasing power and luxury expenditure style as compare to others like baby boomers (Shin et al., 2017). According to Richards (2007), Millennials are also amongst frequent and intrepid travelers who crave 
new experiences. Indian Millennial Travellers (IMT) is found in second place next to the Chinese amongst other Asian Millennial Travellers by Singapore Tourism Board concerning their spending per trip (Duttagupta, 2015). They are tech-savvy and are digitally influenced luxury consumers (Deloitte, 2017). They are effortlessly connected to the global trends (Talreja \& Rajagopalan, 2018) and have higher expectations with brands (CMO.com, 2017). These trends highlight the strategic importance of Millennials in analyzing the development of affordable luxury markets around the world while presenting additional challenges to successfully targeting different demographic cohorts for luxury products and services (Rodrigues \& Rodrigues, 2019).

Considering all these concepts in view, the present study is drafted to draw the theoretical insight into overall luxury service value and travel behavior amongst millennial consumers in India. Since, most of the studies have been defined with consumption of tangible luxury goods, like jewelry or cars whereas despite growth in the market since 2005 , consumption of luxury tourism and hospitality services have very less been analyzed or discussed (Mintel, 2010). The present study investigates the factors that define the value perceptions and attitude of Millennials towards luxury service consumption in India. Commencing with a discussion of literature and studying the various factors like Experiential value, functional value, social value, value for money, novelty value, the hypotheses are developed that are further tested with statistical tools mentioned in the research methodology section, the results are presented and inferences discussed accordingly. This study may help to support the existing knowledge of luxury value and travel patterns of emerging and potential consumers and to develop a theoretical model to validate and analyze the luxury service consumption amongst them. Understanding the concept amongst Indian millennial travelers would help in providing insights enabling a better understanding of behavioral aspects to ensure successful and effective luxury tourism marketing.

\section{ORIGINALITY}

In recent years Indian tourism service industry market has acquired a significant position with its diversity to reach every potential consumer where the millennials with 
enormous purchasing potential have enticed the attention of researchers and marketing practitioners. Most of the research studies have addressed the luxury consumption in terms of goods and more precisely it has been conducted in values associated with tangible goods like mobile phones (Maghnati \& Ling, 2013), cosmetic brands (Ajitha \& Sivakumar, 2017), perfumes, and apparels (Chihab \& Abderrezzak, 2016; Jo, Kim \& Choi, 2020; Woodside \& Fine, 2019). Some studies have focused on the driving force of tourists and developed the luxury value behavior in hotels (Chen \& Peng, 2014), luxury shopping (Correia, Kozak \& Kim, 2019) and were conducted in other destinations whereas the studies that could sufficiently identify the Indian especially millennial consumers' value sets that determine their attitude and intentions to travel or purchase a luxury tourism and hospitality services are still few or lacking. The present study thus intends to fill the gaps in the luxury service literature and practice repertoire by analyzing the factors that determine millennia's attitude towards intentions to travel or purchase the luxury services luxury in India.

\section{LITERATURE REVIEW}

Quoted as "desired by many but accessible to few", as a key underlying feature, possessing luxury service or product is bliss (Berry, 1994). In luxury services, consumption involves customer service and experience (Woodside \& Ko, 2013; Okonkwo, 2016; Kim, Kim \& Choi, 2019). On the other hand, Smith in 1776 explained the concept of consumption through the goods that are "necessary for sustenance", "for individual well-being", "for growth and prosperity", and "luxurious and expensive". In fact, the understanding of luxury varies among individuals (Hennigs et al., 2013), is situational and contingent which depends on the particular experience and the specific needs of the individuals (Wiedmann et al., 2007). Along with technology, entertainment, and food, the tourism sector is expected to attain a momentous share from the consumption of luxury products (Ward and Neumann, 2012). Fedeli (2011) considered that the definition of luxury in tourism is based on the sequence of physical factors along with the personal evaluations and perceptions that tourists attribute to them. In addition, Page in 2014 explains luxury tourism as consumption of a luxurious and premium experience which 
involves availing tailor-made packages and the exclusive services resorts, private jets, where the major concern is given to comfort and luxurious quality standards. While considering the luxury consumption in traveling, Chan et al. (2016) analyzed it as a source of generous experience and depicts an extraordinary quality of life, which draws from Maslow's hierarchy theory of needs where more habituated or familiar a tourist is to luxury, the higher their expectations with the services and for their luxury idea to be fulfilled (Amadeus, 2016). Tourism and hospitality services provide such facilities through desirable experiences like leisure experiences, social events, dining, travel, and wellness practices (Hallott, 2013; Dixit, Lee \& Loo, 2019) where tourists look for exclusive and unusual destinations and activities (Veríssimo \& Loureiro, 2012; Dixit, 2017).

Also, Yeoman and McMahon-Beattie (2010) considered a luxury as experience and legitimacy based rather than prioritizing economic value. However, the frequency of availing the luxury by tourists not only affects their perception level but also increases the expectations with the service experiences (Amadeus, 2016). Where quality remains the primary concern amongst luxury consumers, Asian consumers are called to be derived by the social status attached to such products. However, the overall decision process among luxury travelers are found to be influenced by service quality of the product and service involving integrity and delivery of service, tailored relationship, ease of access, authenticity, and range of the experience associated with the travel services (Horwath HTL's report, 2011). The actual consumption pattern cannot be accurately predicted when people actually have the knowledge about luxury but cannot afford them easily (Chintagunta \& Lee, 2012; Debnam \& Svinos, 2007). In the present study, the millennial consumers are considered to fall in high-income strata who could afford to put the higher fraction of their income on discretionary expenditure, like purchasing luxury products or services (Sekulic \& Sibley, 2007). Hence, to understand the motivations for availing luxury services among tourists, it is crucial to understand the underlying value that the travel products or services have for the potential travelers (Ballantyne \& Varey, 2006).

\section{1) EXPERIENTIAL VALUE}


The experiential value defines the individual's subjective value and taste and derives the hedonic values. Being considered as extraordinary, expensive, and unique, luxury can direct individual perceptions and feelings towards brands that are rare thereby explaining hedonic as well as uniqueness-seeking motivations (Hung et al., 2011; Cavusgil \& Kim, 2014). It induces feelings, desire, and fun that support the consumption of luxury products amongst consumers (Holbrook \& Hirschman, 1982) where Holbrook (2000) further extended the concept to "experience, exhibitionism, entertainment and evangelizing". In the tourism sector service providers are working towards the dimensions that lead to tourists' thinking and feelings attached with the service consumption thereby adding up to their experience value (Batra \& Ahtola, 1991; Yoon \& Lee, 2017) especially for affluent consumers who look for extremely unique services and products (Roux et al., 2017) and defines their attitude towards availing or purchasing such services (Nambisan \& Baron, 2007).

In other words, luxury products and services serve the consumers with the outlook of indulgence and pleasure and subsequently add to their individual and intangible satisfaction (Dubois \& Czellar, 2002). Consumers get encouraged and excited by getting indulged in whatever they like or love (Otto \& Ritchie, 1996). It is all about assessment conducted by consumers for realizing excellence, efficiency, and authenticity of service (Wu \& Liang, 2009; Kim, Ham, Moon, Chua \& Han, 2019) which further defines their attitude in purchasing or availing the luxury service or products (Vigneron \& Johnson, 2004; van Birgelen et al., 2003). The typology used for experiential values is the one proposed by Mathwick, Malhotra and Rigdon (2001) in their study where they examined the experiential values by using experiential value scale (EVS) with four value dimensions including service excellence, aesthetics Customer Return on Investment (CROI) and playfulness. Further, Sweeney and Soutar (2001) defined the consumer's perceived value with functional value, social value, emotional and novelty value. Moreover, in context with luxury value, Wiedmann et al. (2009) defined the terms with the "functional value", "financial value", "the individual value", and the "social value". In contrary to this, Williams and Soutar (2009) explained the experiential value with "functional value", "Value for Money", "Emotional value", "and Social Value" and "Novelty value". 
According to LeBlanc et al. (2015), tourists generally recall the emotions they get during their experiences associated with any travel services or product. In the earlier integrations with experts in the luxury service sector as well as various luxury tourism practitioners, few dimensions were listed out. It is about the efficiency of a service or product that triggers the emotions or feelings of consumers (Sheth et al., 1991; Torres, Wei, Hua \& Chen, 2019). In luxury, service experience is all about emotions (Feng et al., $2018,186)$ where consumers are psychologically driven to retain pleasure and emotional benefits and values (Turunen et al., 2020) thereby influencing the customer attitude towards the product and service (Ruiz-Molina \& Gil-Saura, 2008; Kim et al., 2011). Given all this, the four dimensions were finally carved out for further research process.

\section{2) FUNCTIONAL VALUE}

One of the core characteristics of a product or service is its functionality. According to Sheth et al. (1991), functional value is a major element that drives the consumer's choice. Zeithaml (1988); and Woodruff (1997) defined it as the "value for money" or the value retained for the price paid by the consumer. In terms of luxury service, along with the functional performances, authorities intend to provide expressive values to the tourists or consumers (Guido et al., 2015; Malär et al., 2011). In other words, functional value is the level to which a product or service provides the necessary functions, is convenient, and is endowed with essential features (Smith \& Colgate, 2007; Wu \& Chang, 2016) thus determining the attitude of the consumers towards a service or a product (Maghnati \& Ling, 2013; Wu \& Chang, 2016) thus leading to the proposition:

H1: Functional value affects the attitude of millennial tourists towards luxury hospitality services.

\section{3) SOCIAL VALUE}

Conspicuous consumption of luxury facilitates asserting uniqueness and social superiority (Vigneron \& Johnson, 2004). Seeking luxury travel products and experiences 
helps the tourists tag their social status along with superiority and class (Amaldoss \& Jain, 2005) which relies upon the desire to differentiate them from others (Gupta, 2017). Such kind of expensive self-gift and elite travel experiences satisfy the social esteem and lifestyle of affluent consumers and tourists (Hennigs et al., 2015; Chan, To \& Chu, 2016) which reflect their social position or class and are the significant dimension that reflects their behavior (Martineau, 1958). While considering the social values, consumers tend to consider their social status, image, and desires and refer to the products, which can raise prestige and identity (Wu \& Chang, 2016). Consumers get opportunities to articulate their identities by using luxury services and products (Kurnaz, 2017). Such symbolic, conspicuousness is further been found to influence attitude towards the luxury products and services among people especially Indian consumers (Berthon et al., 2009; Han et al., 2010; Wu \& Chang, 2016; Kurnaz, 2017; Gupta, 2017).

H2: Social value affects the attitude of millennial consumers towards luxury hospitality services.

\section{4) VALUE FOR MONEY / FINANCIAL VALUE}

Consumers tend to purchase luxury brands to depict their status and wealth (Bhanot, Srinivasan \& Srivastava, 2014). Considering the financial value for luxury products Wiedmann et al. (2007) explained it as a price that consumers pay for the product in return for the associated benefits they are looking for. According to Han, Nunes and Drèze (2010), financial value is a motivating source that defines consumer behavior. In general, affluent tourists evaluate the monetary value of products and services that generally raise their expectations in comparison to the price paid for the particular service or products (Tynan et al., 2010; Suki, 2016). In the particular service sector, luxury hospitality consumers wish for services to represent reasonable monetary value (Lee \& Hwang, 2011) which further determines or influences tourists'/consumers' attitudes towards a luxury service (Yang \& Mattila, 2016; Chen, Kladou \& Peng, 2017). 
H3: Financial Value affects the attitude of millennial consumers towards luxury hospitality services.

\section{5) NOVELTYI EPISTEMIC VALUE}

The epistemic or novelty value explains the people's curiosity for attaining difference and diversity (Wang et al., 2013) and is created when a certain product or service stimulates curiosity and provides novelty to satisfy their desires (Sheth et al., 1991). Curiosity is the foundation of epistemic/novelty value among consumers (Miščević, 2017) and is defined as a major value dimension in the tourism sector (; Williams \& Soutar, 2009). Furthermore, the epistemic or novelty value of a product or service relies upon its ability to induce curiosity among consumers to attain novelty or to seek something new to fulfill their desires (Mcalister \& Pessemier, 1982; Alasaad, 2017; Sugandini \& Djawoto, 2018). Accordingly, March (1991); Teah \& Phau (2008) found that novelty influences attitude toward luxury products and services.

H4: Novelty Value affects the attitude of millennial consumers towards luxury hospitality services.

\section{6) ATTITUDE AND INTENTION TO PURCHASE}

Attitude plays a significant role in determining the concept of luxury in consumers' minds (Gupta, 2017). Chen and Liu (2004) posit attitude as the main factor influencing behavioral intention. Attitude refers to a predisposition amongst consumers to favorably or unfavorably respond to certain products or services (Ruiz-Molina \& Gil-Saura, 2008). In terms of tourism, Moutinho (1987) explained the term as tourists' tendency or feelings towards a destination, which depends upon numerous attributes of tourism service. Accordingly, when an attitude is shaped against an action, it leads to the creation of behavioral intentions among consumers (Ajzen, 1991; Chen, 2017; Kim, et al., 2019) thereby influencing the purchase intentions for luxury service/products in the tourism sector (Chen \& Peng, 2014). 
H5: Attitude affects the purchase intentions of millennial tourists towards luxury hospitality services.

Keeping the literature review the conceptual model for the research is framed in the form of figure 1 and tested accordingly.

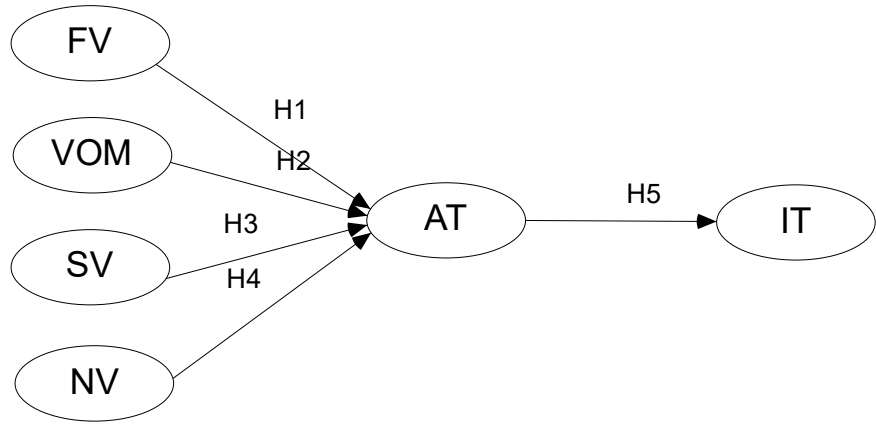

Figure 1: Conceptual Model of the Research

\section{RESEARCH METHODOLOGY}

The study quantitatively tries to investigate the factors that define the value perceptions and attitude of Millennials towards luxury service consumption in India. Accordingly, a structured questionnaire was utilized to understand the presumptions. The scale was adopted from the study of Prebensen and Rosengren (2016); Wiedmann et al. (2009); Williams and Soutar (2009); and Al-hajla (2017) which was further reframed in accordance with the present research. Accordingly, 4-dimensions were finally taken after reviewing the adequate literature and consulting the subject and industrial experts where during pretesting process 4-dimension scale was developed consisting of "functional value", "value for money", "novelty value", and social value" and were finally modified by the context of the present research.

Similarly, the scale for attitude was measured using four items adapted from the studies conducted by Ruiz-Molina and Gil-Saura (2008); Ajzen (1991); Chen and Peng (2014), and the scale for intentions to purchase luxury travel services was reframed in 
reference with the scale given Kim et al. (2011); Summers et al. (2006); Ajzen (1991) and Zhang and Kim (2013). All the items were measured using a 7-point Likert scale where $1=$ highly agree and $7=$ highly disagree.

Since the research focuses on millennial consumers in India, the respondents who fall under the age bracket of 24 to 35 were approached as they are supposed to have spending power and are assumed to indulge more in experiential travel to destinations (Sofronov, 2018). To give a more refined approach, respondents with an annual income of more than $\$ 34000$ were selected for data collection keeping in view the affordability of services, and only such respondents were considered under the concept of luxury travel consumers. Moreover, a filter question "Have you ever purchased a luxury service?" was added at the start of the questionnaire and only a 'Yes' answer would make the subsequent responses valid. In particular, consumers who hail from Tier-1 and Tier-2 cities like Delhi, Chandigarh, Pune, and Mumbai (defined by the Reserve Bank of India as per the 2001 census) in India were considered. A purposive sampling technique was applied to select the respondents who were the consumers/travelers who have had experienced or purchased any of the luxury travel services at least once. Whereas exact population size was not available, about 600 respondents were targeted (Lomax \& Schumacker, 2004) and questionnaires were distributed online of which only 524 were received back while only 496 responses were found reliable and were finally utilized for the analysis process.

\section{DATA ANALYSIS AND INTERPRETATION}

\section{1) DEMOGRAPHICS}

The sample of 496 respondents consisted of 273 males (55.04\%) and 223 females $(44.9 \%)$. In terms of educational qualification, approx. $42 \%$ of respondents were having a graduate degree, $44 \%$ were having a Master's Degree and $13.7 \%$ of respondents were having a Ph.D. or a higher education background. Respondents that have ever consumed any luxury travel service were asked to proceed with the questionnaire, to retain reliable responses for the research. 


\section{2) RELIABILITY AND VALIDITY OF MEASUREMENT SCALE ANALYSIS}

Since Structural Equation Modelling (SEM) analysis provides the dual aspects of tests including Confirmatory Factor Analysis (CFA) and Path Analysis, these were utilized to analyze the data where the results for all the factors for defining reliability and validity for research, explained very good results. AMOS 16.0 software was utilized for testing the SEM for this research.

Accordingly, factor loadings depicted significant loadings on their respective dimensions and in fact, all the loadings were above .50 thereby explaining a good convergent validity for each dimension. Also the Composite Reliability ( $C R \geq 0.6)$, Average Variance Extracted (AVE $\geq 0.5$ ) and $\alpha$-value $(0.75)$ were in the given range of threshold criteria (Awang, 2015; Hair et al., 2014) which also indicated a good reliability and validity adopted scale (Table 1). Before proceeding with the tests, data normality was ensured using the $Q-Q$ plot. This plot evaluates the empirical quantiles of sample data with the subsequent quantiles of a speculative distribution, previously selected (Das et al., 2016).

Moreover, the correlation matrix and Discriminant Validity has been defined and explained in Table 2. This again reflects the validity of the chosen dimensions for further analysis as the values are found to be appropriate and aligned with the given criteria (Hair et al., 2014). The analysis showed that Indian luxury travelers pay maximum focus to the quality of the service $(r=0.685)$ when they are thinking of the functionality of the luxury service. It also showed that out of all the values, respondents are inclined towards the Novelty Value the most $(\alpha=0.890)$ showing the highest loading. The respondents felt that luxury services provided a consistent level of quality $(\alpha=0.685)$ while it helps them to feel more social status $(\alpha=0.730)$ and express themselves $(\alpha=0.790)$ where the amounts paid by them was considered acceptable $(\alpha=0.791)($ Table 1$)$.

\begin{tabular}{|c|c|c|c|c|c|c|}
\hline Dimensions & Codes & Variables & Loadings & $\alpha$ & CR & AVE \\
\hline \multirow[b]{2}{*}{ Functional Value } & F1 & $\begin{array}{l}\text { Luxury tourism and services provide a } \\
\text { consistent level of quality }\end{array}$ & 0.685 & \multirow{2}{*}{0.741} & \multirow[b]{2}{*}{0.873} & \multirow[b]{2}{*}{1.377} \\
\hline & F2 & $\begin{array}{c}\text { Luxury destinations and services are } \\
\text { aesthetically appealing }\end{array}$ & 0.654 & & & \\
\hline
\end{tabular}




\begin{tabular}{|c|c|c|c|c|c|c|}
\hline & F3 & $\begin{array}{l}\text { Luxury travel services are endorsed } \\
\text { with an acceptable level of quality }\end{array}$ & 0.583 & & & \\
\hline & $\mathrm{F} 4$ & Luxury service is well organized & 0.530 & & & \\
\hline \multirow{4}{*}{ Value for Money } & VOM1 & $\begin{array}{l}\text { I found Luxury services as reasonably } \\
\text { priced }\end{array}$ & 0.625 & \multirow{4}{*}{0.781} & \multirow{4}{*}{0.903} & \multirow{4}{*}{1.625} \\
\hline & VOM2 & $\begin{array}{l}\text { The amount paid for luxury travel and } \\
\text { serves are acceptable to me }\end{array}$ & 0.791 & & & \\
\hline & VOM3 & $\begin{array}{l}\text { Luxury travel services represent "value" } \\
\text { for money }\end{array}$ & 0.622 & & & \\
\hline & VOM4 & $\begin{array}{l}\text { I found luxury services as appropriately } \\
\text { priced }\end{array}$ & 0.667 & & & \\
\hline \multirow{6}{*}{ Social Value } & SV1 & It helps me to meet likeminded people & 0.586 & \multirow{6}{*}{0.833} & \multirow{6}{*}{0.905} & \multirow{6}{*}{1.116} \\
\hline & SV2 & $\begin{array}{l}\text { Participating in luxury travel } \\
\text { experiences helps to create a good } \\
\text { impression }\end{array}$ & 0.626 & & & \\
\hline & SV3 & $\begin{array}{c}\text { It helps me communicate my } \\
\text { self-identity }\end{array}$ & 0.651 & & & \\
\hline & SV4 & $\begin{array}{l}\text { It makes me feel more socially } \\
\text { accepted }\end{array}$ & 0.674 & & & \\
\hline & SV5 & $\begin{array}{l}\text { It is considered a symbol of social } \\
\text { status }\end{array}$ & 0.730 & & & \\
\hline & SV6 & It helps me to express myself. & 0.790 & & & \\
\hline \multirow{6}{*}{ Novelty Value } & NV1 & It satisfies my curiosity & 0.768 & \multirow{6}{*}{0.890} & \multirow{6}{*}{0.949} & \multirow{6}{*}{1.582} \\
\hline & NV2 & It is an authentic/genuine experiences & 0.845 & & & \\
\hline & NV3 & It is a unique kind of experience & 0.713 & & & \\
\hline & NV4 & It is kind of educational & 0.743 & & & \\
\hline & NV5 & It gives the pleasure of self-indulgence. & 0.672 & & & \\
\hline & NV6 & It has a personal uniqueness & 0.831 & & & \\
\hline \multirow{4}{*}{ Attitude } & AT1 & Experiencing luxury services is good & 0.683 & \multirow{4}{*}{0.818} & \multirow{4}{*}{0.896} & \multirow{4}{*}{1.542} \\
\hline & AT2 & $\begin{array}{l}\text { Luxury services give a pleasant } \\
\text { experience }\end{array}$ & 0.660 & & & \\
\hline & AT3 & $\begin{array}{l}\text { Availing Luxury travel products or } \\
\text { services makes me feel rewarded }\end{array}$ & 0.649 & & & \\
\hline & AT4 & $\begin{array}{l}\text { It is beneficial to experience luxury } \\
\text { services and products }\end{array}$ & 0.662 & & & \\
\hline \multirow{3}{*}{ Intentions } & IT1 & $\begin{array}{l}\text { I would like to purchase luxury travel } \\
\text { services and product }\end{array}$ & 0.916 & \multirow{3}{*}{0.934} & \multirow{3}{*}{0.975} & \multirow{3}{*}{3.274} \\
\hline & IT2 & $\begin{array}{c}\text { My willingness to experience Luxury } \\
\text { travel service is high. }\end{array}$ & 0.908 & & & \\
\hline & IT3 & $\begin{array}{l}\text { I intend to buy Luxury travel in the } \\
\text { future. }\end{array}$ & 0.890 & & & \\
\hline
\end{tabular}

Note: $\alpha=$ Cronbach alpha, $C R=$ Composite Reliability, AVE=Average Variance Extracted Table1: Reliability and Validity of Measurement Scale

\begin{tabular}{|c|c|c|c|c|c|c|}
\hline & NV & SV & VOM & $\mathrm{FV}$ & AT & IT \\
\hline NV & 1.25 & & & & & \\
\hline SV & 0.607 & 1.05 & & & & \\
\hline VOM & 0.729 & 0.623 & 1.27 & & & \\
\hline FV & 0.509 & 0.577 & 0.497 & 1.73 & & \\
\hline AT & 0.781 & 0.875 & 0.811 & 0.724 & 1.24 & \\
\hline IT & 0.670 & 0.751 & 0.696 & 0.622 & 0.858 & 1.90 \\
\hline
\end{tabular}




\section{3) HYPOTHESES TESTING}

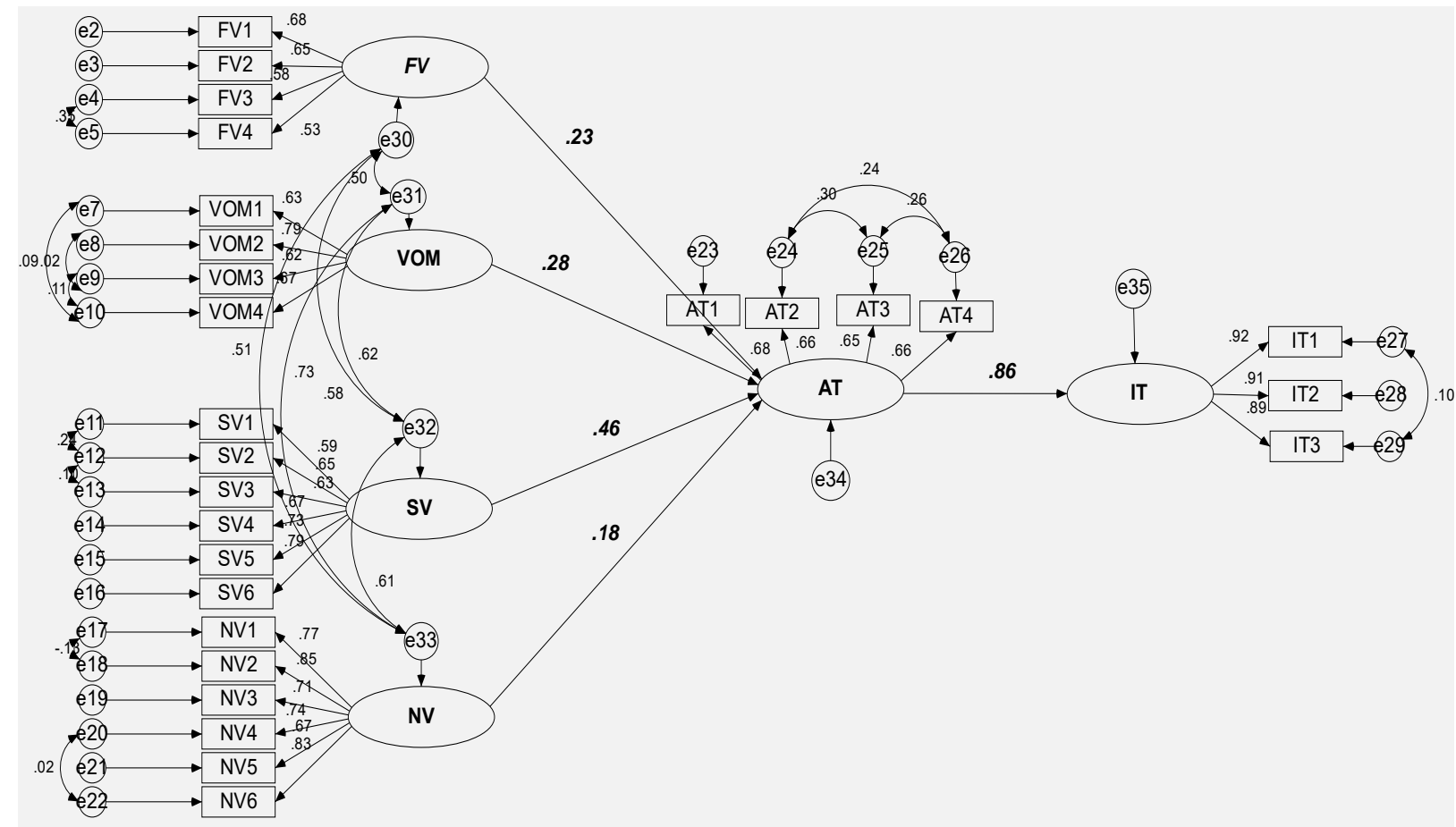

Note: FV= Functional Value, VOM=Value for Money, SV=Social Value, NV= Novelty, $A T=A t t i t u d e, I T=I n t e n t i o n s$, e1e33=error terms

Figure 2: Research Model

The final tested model for explaining the relationship between the various factors undertaken for the study is explained in figure 1. To draft the actual status of the overall SEM model certain modifications in the final model were conducted during the test. Analysis revealed a good model fit for the tested model, where CMIIN/df=2.035 is found significant as $p=0.000$. Accordingly, the values for a good measurement model are found by the range of given fit indices where RMSEA=0.046, $A G F I=0.902, G F I=0.922$, $\mathrm{RMR}=0.061, \mathrm{NFI}=0.918, \mathrm{IFI}=0.957, \mathrm{TLI}=0.949, \mathrm{CFI}=0.956$. From this viewpoint, $\mathrm{H} 1$ to $\mathrm{H} 4$ testing the influence of value dimensions on millennia's attitude for luxury travel services were supported. The results depict that although overall experiential values including functional value $(F V)(H 1)(\beta=0.228, p<0.001)$, Social Value $(S V)(H 2)(\beta=0.458$, $p<0.001)$, Value for Money/Financial Value (VOM) $(H 3)(\beta=0.279, p<0.001)$, and Novelty 
Value (NV) $(\mathrm{H} 4)(\beta=0.183, p<0.001)$ have a significant influence on attitude of respondents.

Further, the path analysis between the attitude and intention to purchase luxury travel services also revealed that attitude has a significant and positive influence on millennia's intentions to purchase $(\beta=0.858, p<0.001)$ luxury services in India, thereby supporting the $\mathrm{H} 5$ of the present study (Figure 2). Thus, it explains the mediation role of attitude in value perceptions and purchase of luxury travel services.

\section{CONCLUSION AND IMPLICATIONS}

The objective of this study was to identify the experiential values that influence or affects Indian millennials ' attitudes towards purchasing luxury travel services. As influencing dimensions four major factors including Functional Value, Value for Money/Financial Value, Social Value, and Novelty Value were identified based on the review of literature related to luxury services and tourism. The impact of travelers' attitudes on their intentions to purchase luxury tourism services was further analyzed. The results of the present research provide valuable insights about potential travel segments that have a positive attitude towards purchasing luxury tourism and hospitality service goods. It was initially thought that value is developed by the company or the firm offering the solution and gets profit in return of that which over the years was augmented that it is more or less a customer-driven process and both the company and the customer cocreate them (Eggert et al., 2018) before, during and post-delivery stages (Payne et al., 2020).

The findings revealed social value as an important factor that influences the attitude of millennial consumers towards purchasing luxury tourism services. This result is consistent with research conducted by Al-hajla (2017) indicated a significant relationship between symbolic values and luxury consumption behavior including purchase intentions. Respondents of present research explain the similarity of socially conscious consumers as discussed by Kurnaz (2017) and Gupta (2017). Attaining the services with a value that makes the millennial convey the impression of high standards 
and status in the society consequently influences their attitude towards the luxury services.

Nevertheless, the millennial consumers are found considering the service that depicts Financial Values or Value for Money that influence their attitude towards purchasing the luxury tourism services in India which may be because higher prices are considered as a cue for representing prestige associated with status, prestige, and quality (Deeter-Schmelz et al., 2001).

The analysis also revealed a significant and positive influence of functional values on the attitude of millennial travelers and the results are also found aligned with the study of Stanforth and Lee (2011) according to which consumers generally evaluate functional values of intangible product or services and their quality following its price and exclusivity they are charged. In other words, millennials in India prefer luxury services that could fall at par with their social, innovative, financial, and functional value expectations (Wiedmann et al., 2007; 2009) thereby influence their overall travel practices and intentions to purchase such services.

Hence, marketers are suggested to communicate a value and consider value dimensions while promoting the luxury service and products among potential travel segment in India. Along with providing a theoretical model for behavior, the study provides insights into measuring tourist value preference by utilizing empirical data within luxury tourism contexts and suggests the tourism and hospitality business practitioners make innovations in product, service management, and marketing to draw the attention of such potential segment.

\section{LIMITATIONS AND DIRECTIONS FOR FURTHER RESEARCH}

Like any other research, this study also witnessed certain limitations like limited time, distance, and resources. Since the data was collected only from Tier-1 and Tier-2 cities; the respondents from other cities could also be further studied to make the results more comprehensive. Also, the study is limited to millennials whereas the results may vary and can be tested in other consumer cohorts like generation $X$ in the future. The respondents may also vary in their choices following their cities they are living or working. 
It is advisable to carry out a comparative analysis between various groups based on their demographics, income level travel practices, choices, and the services are undertaken. Moreover, no mediation or moderation was conducted; the future study with such effects with other extrinsic variables can also be processed to getter better insights into the attitude of millennials towards luxury service consumption.

\section{References}

Ajitha, S.; Sivakumar, V.J. Understanding the effect of personal and social value on attitude and usage behaviour of luxury cosmetic brands. Journal of Retailing and Consumer Services, Vol. 39, No November, 2017 pp. 103-113.

Ajzen, I. The Theory of planned behaviour. Organizational Behaviour and Human Decision Processes, Vol. 50, No. 2, 1991, pp. 179-211.

Alasaad, R. Overall value assessment of luxury accessories brands: Antecedents and consequences from the perspectives of Gulf Arab tourists. Doctoral thesis, Brunel University London, 2017. Retrieved from https://bura.brunel.ac.uk/handle/2438/14236 (accessed 20 January 2020).

Al-hajla, A.H. Luxury hospitality values regarding luxury hotels and the role of religious values in the Islamic market. Journal of Tourism, Hospitality and Sports, Vol. 32, 2017, pp. 39-50.

Amaldoss, W.; Jain, S. Pricing of conspicuous goods: A competitive analysis of social effects. Journal of Marketing Research, Vol. 42, No.1, 2005, pp. 30-42.

Awang, Z. SEM made simple: A gentle approach to learning Structural Equation Modeling. Bangi Selangor, Malaysia: MPWS Rich Publication, 2015. 
Ballantyne, D.; Varey, R.J. Creating value-in-use through marketing interaction: the exchange logic of relating, communicating and knowing", Marketing Theory, Vol. 6, No. 3, 2006, pp. 335-348.

Batra, R.; Ahtola, O.T. Measuring the hedonic and utilitarian sources of consumer attitudes. Marketing Letters, Vol. 2, No. 2, 1991, pp. 159-170.

Berry, C.J. The idea of luxury: A conceptual and historical investigation (Vol. 30). England: Cambridge University Press, 1994.

Berthon, P.; Pitt, L.; Parent, M.; Berthon, J.P. Aesthetics and ephemerality: observing and preserving the luxury brand. California Management Review, Vol. 52, No. 1, 2009, pp. 45-66.

Bhanot, S.; Srinivasan, R.; Srivastava, R.K. Influence of ethnicity on uniqueness \& snob value in purchase behaviour of luxury brands. Journal of Research in Marketing, Vol. 2, No.3, 2014, pp. 172-186.

Cavusgil, E.; Kim, D. Hedonic vs. Utilitarian Perspective of Retail Store Loyalty: Insights from a National Study of Households. Kilts Center for Marketing at Chicago BoothNielsen Dataset Paper Series, 2014, pp. 1-20.

Chan, W.Y.; To, C.K.M.; Chu, W.C. Desire for experiential travel, avoidance of rituality and social esteem: An empirical study of consumer response to tourism innovation. Journal of Innovation \& Knowledge, Vol. 1, No.1, 2016, pp. 24-35.

Chen, A.; Kladou, S.; Peng, N. Incorporating vanity into a luxury Value-Attitude-Behaviour Model-Evidence from luxury restaurant consumers, In: Association for Consumer Research (ACR) Conference, San Diego, California, 26-29th October, 2017. Retrieved from 
http://shura.shu.ac.uk/17089/1/Kladou\%20Incorporating\%20vanity\%20into\%20a\%20lux ury.pdf (accessed 14 February 2020).

Chen, A.; Peng, N. Examining Chinese consumers' luxury hotel staying behavior. International Journal of Hospitality Management, Vol. 39, No. May, 2014 pp. 53-56.

Chen, K.J.; Liu, C.M. Positive brand extension trial and choice of parent brand. Journal of Product \& Brand Management, Vol. 13, No.1, 2004, pp. 25-36.

Chen, P.J. Ego involvement, Service Performance and Customer Satisfaction. In Global Conference on Services Management (GLOSERV 2017), Vol. 10, 2017, p. 311.

Chihab, Z.O.; Abderrezzak, B. Factors affecting consumer purchase intention of luxury perfumes in Algeria: A case study of consumers in the twin cities of Tlemcen and Sidi Bel Abbes. Journal of Research in Marketing, Vol. 6, No. 3, 2016, pp. 461-467.

Chintagunta, P.; Lee, J. A pre-diffusion growth model of intentions and purchase. Journal of the Academy of Marketing Science, Vol. 40, No. 1, 2012, pp. 137-154.

CMO.com. Affluent Millennials in India say they're 'supercharged' about native advertising. March, $2017 . \quad$ Retrieved from https://blog.adobe.com/en/publish/2017/03/02/affluent-millennials-in-indiasupercharged-about-native-advertising.html (accessed 29 July 2020).

Correia, A.; Kozak, M.; Kim, S. Investigation of luxury values in shopping tourism using a fuzzy-set approach. Journal of Travel Research, Vol. 58, No.1, 2019, pp. 77-91.

Das, K.R.; Imon, A.H.M.R. A brief review of tests for normality. American Journal of Theoretical and Applied Statistics, Vol. 5, No. 1, 2016, pp. 5-12. 
Debnam, N.; Svinos, G. Luxury brands in China. KPMG, 2007. Retrieved from https://www.claridenglobal.com/knowledge at clariden/CM Luxury brand.pdf (accessed 25 September 2019).

Deeter-Schmelz, D.R.; Bizzari, A.; Graham, R.; Howdyshell, C. Business to business online purchasing: suppliers' impact on buyers' adoption and usage intent. Journal of Supply Chain Management, Vol. 37, No. 4, 2001, pp. 4-10.

Deloitte. Global Powers of Luxury Goods 2017. Retrieved from https://www2.deloitte.com/content/dam/Deloitte/global/Documents/consumer-industrialproducts/gx-cip-global-powers-luxury-2017.pdf (accessed 26 January 2020).

Deloitte. Trend-setting millennials. Redefining the consumer story. February, 2018. Retrieved from https://rls.net.in/wp-content/uploads/2018/02/TrendsettingMillenials RAI-Deloitte.pdf (accessed 24 December 2019).

Dixit, S.K. (Ed.). The Routledge handbook of consumer behaviour in hospitality and tourism. UK: Taylor \& Francis, 2017.

Dixit, S.K.; Lee, K.H.; Loo, P.T. Consumer behaviour in hospitality and tourism. Journal of Global Scholars of Marketing Science, Vol. 29, No. 2, 2019, pp. 151-161.

Dubois, B.; Czellar, S. Prestige brands or luxury brands? An exploratory inquiry on consumer perceptions. Université de Genève, 2002. Retrieved from https://archiveouverte.unige.ch/unige:5816 (accessed 28 January 2020).

Duttagupta, S. How Indian 'millennial' travellers are driving new trends by shunning sightseeing \& fixed itineraries. The Economic Times, 2015. Retrieved from https://economictimes.indiatimes.com/articleshow/49703206.cms?utm source=contento fintert (accessed January 5, 2020). 
Dykins R. Shaping the Future of Luxury Travel: Future Traveller Tribes 2030. Amadeus, 2016. Retrieved from http://www.amadeus.com/msite/globalreport/2016/en/pdf/whitepapers/shaping-the-future-of-luxury-travel-report.pdf (accessed 26 January 2020).

Eggert, A.; Ulaga, W.; Frow, P.; Payne, A. Conceptualizing and communicating value in business markets: From value in exchange to value in use. Industrial Marketing Management, Vol. 69, 2018, pp. 80-90.

Falk, N.J. What you need to know about luxury consumer trends for 2018. December 29, 2017. Retrieved from https://www.forbes.com/sites/njgoldston/2017/12/29/what-youneed-to-know-about-luxury-consumer-trends-for-2018/?sh=366b018921eb (accessed 29 July 2020).

Fedeli, G. (2011). The Luxury Side of Tourism and China: A Qualitative Study of Motivations and National Values of the Affluent Mainland Chinese Leisure Traveller in Sydney Australia. Master thesis, NHTV University of Applied Sciences, 2011. Retrieved from

https://www.researchgate.net/publication/328830006 The luxury side of tourism and China A qualitative study of motivations and national values of the affluent Mai nland Chinese leisure traveller in Sydney Australia (accessed 2 June 2021).

Feng, R.; Wang, Y.C.; Ryan, B. Service Experiences at Luxury Hotels. In Quality Services and Experiences in Hospitality and Tourism. Emerald Publishing Limited, 2018.

Guido, G.; Peluso, A.M.; Capestro, M.; Miglietta, M. An Italian version of the 10-item Big Five Inventory: An application to hedonic and utilitarian shopping values. Personality and Individual Differences, Vol. 76, No. April, 2015, pp.135-140. 
Gupta, S. Consumption of Luxury Brands: An Insight into Consumer Purchase Intention. Doctoral Thesis, University of Jammu, 2017. Retrieved from http://hdl.handle.net/10603/212378 (accessed 22 November 2020).

Hair Jr, J.F.; Sarstedt, M.; Hopkins, L.; Kuppelwieser, V.G. Partial Least Squares Structural Equation Modeling (PLS-SEM). European Business Review, Vol. 26, No. 2, 2014, pp. 106-121.

Hallott, A. The future potential for developing luxury tourism and hospitality in Lapland. Master Thesis, Haga Heli: University of Applied Science, 2013. Retrieved from https://www.theseus.fi/handle/10024/67399 (accessed 12 April 2020).

Han, Y.J.; Nunes, J.C.; Drèze, X. Signaling status with luxury goods: The role of brand prominence. Journal of Marketing, Vol. 74, No. 4, 2010, pp.15-30.

Hanzaee, K.H.; Sadeghian, M. The impact of corporate social responsibility on customer satisfaction and corporate reputation in automotive industry: Evidence from Iran. Journal of Islamic Marketing, Vol. 5, No.1, 2014, pp. 125-143.

Hennigs, N.; Wiedmann, K.P.; Klarmann, C.; Behrens, S. Sustainability as part of the luxury essence: Delivering value through social and environmental excellence. Journal of Corporate Citizenship, No. 52, 2013, pp.25-35.

Holbrook, M.B.; Hirschman, E.C. The experiential aspects of consumption: Consumer fantasies, feelings, and fun. Journal of Consumer Research, Vol. 9, No. 2, 1982, pp. 132140.

Holbrook, M.B. The millennial consumer in the texts of our times: Experience and entertainment. Journal of Macromarketing, Vol. 20, No. 2, 2000, pp. 178-192. 
Horwath HTL. Horwath HTL Report at the International Luxury Travel Market (ILTM) identifies 'The Future of Luxury Travel'. 2011. Retrieved from https://www.hospitalitynet.org/news/4051855.html (accessed 15 January 2020).

Howe, N. A generation to define a century, In Association for Supervision and Curriculum Development Annual Conference. Chicago, IL, 2006, pp. 1-6.

Hung, K.P.; Chen, A.H.; Peng, N.; Hackley, C.; Tiwsakul, R.A.; Chou, C.L. Antecedents of luxury brand purchase intention. Journal of Product \& Brand Management, Vol. 20, No. 6, 2011, pp. 457-467.

Jo, W.; Kim, J.J.; Choi, J. Who are the multichannel shoppers and how can retailers use them? Evidence from the French apparel industry. Asia Pacific Journal of Marketing and Logistics, Vol. 33, No. 1, 2020, pp. 250-274.

Kim, H.W.; Gupta, S.; Koh, J. Investigating the intention to purchase digital items in social networking communities: A customer value perspective. Information \& Management, Vol. 48, No. 6, 2011, pp. 228-234.

Kim, S.J.; Kim, K.H.; Choi, J. The role of design innovation in understanding purchase behaviour of augmented products. Journal of Business Research, Vol. 99, No. June, 2019, pp. 354-362.

Kim, S.; Ham, S.; Moon, H.; Chua, B.L.; Han, H. Experience, brand prestige, perceived value (functional, hedonic, social, and financial), and loyalty among GROCERANT customers. International Journal of Hospitality Management, Vol. 77, No. January, 2019, pp. 169-177.

Kurnaz, A. Examination of the relationship between luxury value perception and shopping motivations: Turkey sample. International Journal of Marketing Studies, Vol. 9, No. 5, 2017, pp. 108-124. 
LeBlanc, V.R.; McConnell, M.M.; Monteiro, S.D. Predictable chaos: a review of the effects of emotions on attention, memory and decision making. Advances in Health Sciences Education, Vol. 20, No. 1, 2015, pp. 265-282.

Lee, J. H.; Hwang, J. Luxury marketing: the influences of psychological and demographic characteristics on attitudes toward luxury restaurants. International Journal of Hospitality Management, Vol. 30, No. 3, 2011, pp. 658-669.

Lomax, R.G.; Schumacker, R.E. A beginner's guide to structural equation modeling. London: Psychology Press, 2004.

Maghnati, F.; Ling, K.C. Exploring the relationship between experiential value and usage attitude towards mobile apps among the smartphone users. International Journal of Business and Management, Vol. 8, No. 4, 2013, pp. 1-13.

Malär, L.; Krohmer, H.; Hoyer, W.D.; Nyffenegger, B. Emotional brand attachment and brand personality: The relative importance of the actual and the ideal self. Journal of Marketing, Vol. 75, No. 4, 2011, pp. 35-52.

March, J.G. Exploration and exploitation in organizational learning. Organization Science, Vol. 2, No.1, 1991, pp. 71-87.

Martineau, P. Social Glasses and Spending Behaviour. Journal of Marketing, Vol. 23, No. 2, 1958, pp. 121-130.

Mathwick, C.; Malhotra, N.; Rigdon, E. Experiential value: conceptualization, measurement and application in the catalog and Internet shopping environment. Journal of Retailing, Vol. 77, No. 1, 2001, pp. 39-56. 
McAlister, L.; Pessemier, E. Variety seeking behaviour: An interdisciplinary review. Journal of Consumer Research, Vol. 9, No. 3, 1982, pp. 311-322.

Mintel. Luxury Holidays-UK-June 2010. Retrieved from https://reports.mintel.com/display/479948/\# (accessed 20 July 2020).

Miščević, N. Epistemic value. Curiosity, knowledge and response-dependence. Croatian Journal of Philosophy, Vol. 16, No. 3, 2017, pp. 393-418.

Moutinho, L. Consumer behaviour in tourism. European Journal of Marketing, Vol. 21, No.10, 1987, pp. 5-44.

Nambisan, S.; Baron, R.A. Interactions in virtual customer environments: Implications for product support and customer relationship management, Journal of Interactive Marketing, Vol. 21, No. 2, 2007, pp. 42-62.

Okonkwo, U. Luxury fashion branding: trends, tactics, techniques. UK: Springer, 2016.

Otto, J.E.; Ritchie, J.B. The service experience in tourism. Tourism Management, Vol. 17, No. 3, 1996, pp. 165-174.

Page, S.J. Tourism Management. UK: Routledge, 2014.

Payne, A.; Frow, P.; Steinho, L.; Eggert, A. Toward a comprehensive framework of value proposition development: From strategy to implementation. Industrial Marketing Management, Vol. 87, 2020, pp. 244-255.

Popescu, I.V.; Olteanu, V. Luxury Tourism: Characteristics and Trends of the Behaviour of Purchase. SEA: Practical Application of Science, Vol. 2, No. 2, 2014, pp. 319-324. 
Prebensen, N.K.; Rosengren, S. Experience value as a function of hedonic and utilitarian dominant services. International Journal of Contemporary Hospitality Management, Vol. 28, No. 1, 2016, pp. 113-135.

Richards, G. New Horizons II-The Young Independent Traveller. WYSE Travel Confederation, 2007. Retrieved from https://www.wysetc.org/research/reports/newhorizons-series/new-horizons-ii-the-young-independent-traveller/ (accessed 2 August 2020).

Rodrigues, C.; Rodrigues, P. Brand love matters to Millennials: the relevance of mystery, sensuality and intimacy to neo-luxury brands. Journal of Product \& Brand Management, Vol. 28/7, 2019, pp. 830-848.

Roux, E.; Tafani, E.; Vigneron, F. Values associated with luxury brand consumption and the role of gender. Journal of Business Research, Vol. 71, No. February, 2017, pp. 102113.

Ruiz-Molina, M.E.; Gil-Saura, I. Perceived value, customer attitude and loyalty in retailing. Journal of Retail \& Leisure Property, Vol. 7, No. 4, 2008, pp. 305-314.

Sekulic, A.; Sibley, N. Understanding the affluent consumers of China. MasterCard Worldwide Insights, Second Quarter 2007. Retrieved from http://anyflip.com/rzkv/pvnc (accessed 2 January 2020.

Seo, Y.; Kelleher, C.; Brodie, R.J. Broadening brand engagement within the servicecentric perspective. Journal of Service Theory and Practice, Vol. 27, No. 2, 2017, pp. 317335.

Sheth, J.N.; Newman, B.I.; Gross, B.L. Why we buy what we buy: A theory of consumption values. Journal of Business Research, Vol. 22, No. 2, 1991, pp. 159-170. 
Shin, H.; Eastman, J.K.; Mothersbaugh, D. The effect of a limited edition offer following brand dilution on consumer attitudes toward a luxury Brand. Journal of Retailing and Consumer Services, Vol. 38, No. 9, 2017, pp. 59-70.

Smith, A. An Inquiry into the Nature and Causes of the Wealth of Nations (The Glasgow Edition of the Works and Correspondence of Adam Smith, Vol. 2, 1776). UK: Oxford University Press, 1976.

Smith, J.B.; Colgate, M. Customer value creation: a practical framework. Journal of Marketing Theory and Practice, Vol. 15, No.1, 2007, pp. 7-23.

Sofronov, B. Millennials: A New Trend for the Tourism Industry. Annals of Spiru Haret University. Economic Series, Vol. 18, No. 3, 2018, pp. 109-122.

Stanforth, N.; Lee, S.H. Luxury perceptions: A comparison of Korean and American consumers. Journal of Global Fashion Marketing, Vol. 2, No. 2, 2011, pp. 95-103.

Sugandini, D.; Djawoto, D. The Influence of Advertising, Knowledge, and Attitudes towards Electricity-Saving Behaviour. Review of Integrative Business and Economics Research, Vol. 7, No. 3, 2018, pp. 172-180.

Suki, N. Green product purchase intention: impact of green brands, attitude, and knowledge. British Food Journal, Vol. 118, No. 12, 2016, pp. 2893-2910.

Summers, T.A.; Belleau, B.D.; Xu, Y. Predicting purchase intention of a controversial luxury apparel product. Journal of Fashion Marketing and Management: An International Journal, Vol. 10, No. 4, 2006, pp. 405-419.

Sweeney, J.C.; Soutar, G.N. Consumer perceived value: The development of a multiple item scale. Journal of Retailing, Vol. 77, No. 2, 2001, pp. 203-220. 
Talreja, A.; Rajagopalan, K. Trend-setting millennials: Redefining the consumer story. Deloitte India and the Retailers Association of India. February 2018. Retrieved from https://rls.net.in/wp-content/uploads/2018/02/Trendsetting-Millenials RAl-Deloitte.pdf (accessed 15 July 2020).

Teah, M.; Phau, I. Attitudes towards counterfeits of luxury brands: The Singapore story, In Proceedings of Australian and New Zealand Marketing Academy Conference 2008, University of Western Sydney, pp. 1-8.

Torres, E.N.; Wei, W.; Hua, N.; Chen, P.J. Customer emotions minute by minute: How guests experience different emotions within the same service environment. International Journal of Hospitality Management, Vol. 77, No. January, 2019, pp. 128-138.

Turunen, L.L.M.; Cervellon, M.C.; Carey, L.D. Selling second-hand luxury: Empowerment and enactment of social roles. Journal of Business Research, Vol.116, No. August, 2020, pp. 474-481.

Tynan, C.; McKechnie, S.; Chhuon, C. Co-creating value for luxury brands. Journal of Business Research, Vol. 63, No. 11, 2010, pp. 1156-1163.

van Birgelen, M.; de Ruyter, K.; Wetzels, M. The impact of attitude strength on customeroriented priority setting by decision-makers: An empirical investigation. Journal of Economic Psychology, Vol. 24, No. 6, 2003, pp. 763-783.

Veríssimo, M.; Loureiro, S.M.C. Experience marketing and the luxury travel industry. Book Proceedings-Tourism \& Management Studies International Conference Algarve 2012, Vol. 1, 2013, pp. 296-302.

Vigneron, F.; Johnson, L.W. Measuring perceptions of brand luxury. Journal of Brand Management, Vol. 11, No. 6, 2004, pp. 484-506. 
Wang, H.Y.; Liao, C.; Yang, L.H. What affects mobile application use? The roles of consumption values. International Journal of Marketing Studies, Vol. 5, No. 2, 2013, pp. 11-22.

Ward, K.; Neumann, F. Consumer in 2050. The rise of the EM middle class. HSBC Global Research, $2012 . \quad$ Retrieved from https://www.lampadia.com/assets/uploads documentos/0abb2hsbc report consumer in 2050 en.pdf (accessed 19 July 2020).

Wiedmann, K.P.; Hennigs, N.; Siebels, A. Measuring consumers' luxury value perception: a cross-cultural framework. Academy of Marketing Science Review, Vol. 2007, No. 7, 2007, pp. 1-23.

Wiedmann, K.P.; Hennigs, N.; Siebels, A. Value-based segmentation of luxury consumption behaviour. Psychology \& Marketing, Vol. 26, No. 7, 2009, pp. 625-651.

Williams, P.; Soutar, G.N. Value, satisfaction and behavioural intentions in an adventure tourism context. Annals of Tourism Research, Vol. 36, No. 3, 2009, pp. 413-438.

Woodruff, R.B. Customer value: the next source for competitive advantage. Journal of the Academy of Marketing Science, Vol. 25, No. 2, 1997, pp. 139-153.

Woodside, A.G.; Fine, M.B. Sustainable fashion themes in luxury brand storytelling: The sustainability fashion research grid. Journal of Global Fashion Marketing, Vol. 10, No. 2, 2019, pp.111-128.

Woodside, A.G.; Ko, E. (Eds.). Luxury fashion and culture. West Yorkshire: Emerald Group Publishing, 2013. 
Wu, C.H.J.; Liang, R.D. Effect of experiential value on customer satisfaction with service encounters in luxury-hotel restaurants. International Journal of Hospitality Management, Vol. 28, No. 4, 2009, pp. 586-593.

Wu, S.I.; Chang, H.L. The Model of Relationship between the Perceived Values and the Purchase Behaviours toward Innovative Products. Journal of Management and Strategy, Vol. 7, No. 2, 2016, pp. 31-45.

Yang, W.; Mattila, A.S. Why do we buy luxury experiences? Measuring value perceptions of luxury hospitality services", International Journal of Contemporary Hospitality Management, Vol. 28, No. 9, 2016, pp. 1848-1867.

Yeoman, I.; McMahon-Beattie, U. The changing meaning of luxury, In Yeoman, I.; McMahon-Beattie, U. (Eds.). Revenue Management: A Practical Pricing Perspective. UK: Palgrave MacMillan, 2010, pp. 62-85.

Yoon, S.J.; Lee, H.J. Does customer experience management pay off? Evidence from local versus global hotel brands in South Korea. Journal of Hospitality Marketing \& Management, Vol. 26, No. 6, 2017, pp. 585-605.

Zeithaml, V.A. Consumer perceptions of price, quality, and value: a means-end model and synthesis of evidence. Journal of Marketing, Vol. 52, No. 3, 1988, pp. 2-22.

Zhang, B.; Kim, J.H. Luxury fashion consumption in China: Factors affecting attitude and purchase intent. Journal of Retailing and Consumer Services, Vol. 20, No. 1, 2013, pp. 68-79.

Article info: Received 24/11/2020. Accepted 04/06/2021. Refereed anonymously. 